\title{
Chapter 4 \\ Student Creativity and Professional Artwork in a School Food Intervention in Denmark
}

\author{
Dorte Ruge
}

\subsection{Introduction}

Schools are important health settings for children (Jensen and Simovska 2005; SHE Network 2018; Simovska 2012). Impacted by national, regional, and school policies, the experience of health - and particularly nutrition-in schools is entirely subject to the strength of those policies. In Denmark, as in many other countries such as Norway, New Zealand, and Australia, there is no national school food program to ensure proper nutrition during the school day for all students. Parents and caregivers in Denmark are required to prepare and pack lunch and an afternoon snack for students on a daily basis (Sabinsky 2013).

Given the diverse circumstances in which children live, the effect of this policy impacts health and learning inequitably. Students from vulnerable families are more likely to bring insufficient meals from home to school, if they bring any meals at all (Rasmussen et al. 2019). The general legislation for Danish schools, in Danish: Folkeskolen (Retsinformation 2018), prescribes that food and meal systems in schools "can" be supported by municipal systems (Stovgaard et al. 2017). However, the reliance on caregivers to provide food results in a food environment based on "free-choice" (Stovgaard and Wistoft 2018). This can be characterized as a result of a market-driven neoliberal approach, in which families are encouraged to buy all of their food in the supermarket. This situation leads to a certain "supermarketization" of the way that food is organized and talked about in schools. The packed lunch is "from supermarket" and reflects the social status of the family. The quality of the packed lunch varies a lot, and sometimes it is not even brought to school, not eaten in school, or not stored at the right temperature. Furthermore, the packed lunch is often not adequate to cover the nutritional needs for students (Sabinsky 2013; Stovgaard and Wistoft 2018).

\footnotetext{
D. Ruge ( $\triangle)$

University College Lillebelt, Odense, Denmark

e-mail: doru@ucl.dk
} 
This system in Danish schools is especially unfortunate for students from disadvantaged and immigrant families (Brembeck 2009; Rasmussen et al. 2019). In 2014, Denmark engaged in national school reform to improve learning and well-being for all students (Danish Ministry of Education 2019; Simovska et al. 2015). Consequently, school days became longer, and teaching became more goal-oriented. However, research documents report that students are hungry during the school day, as the packed lunch is insufficient to cover their needs (Ruge 2015; Ruge et al. 2017; Stovgaard and Wistoft 2018). The national Health Institute of Public Health, that monitor the Danish HB report on child health in schools, documented that socioeconomic factors greatly determine inequality in health among children and youth in Denmark (Rasmussen et al. 2019).

This situation gives rise to various "local level solutions" that aim to reduce inequity through health promotion initiatives around nutrition practices and food environments in schools. In the absence of appropriate national policy and public school food initiatives, local initiatives have sought to fill the nutritional gap experienced by students in Danish schools. The project "LOMA-lokal mad" (in English: LOMA-local food) represents a municipal- and school-driven example that included an art-based approach. The overall aim of the project was to reduce inequity in health and learning via student development of food- and health-related action competence through participatory food- and creative arts activities (Jensen and Simovska 2005; Ruge 2015; see also Chap.1, in this volume). Its main activities encompassed student participation in planning, cooking, and serving food for peers. The approach integrated cross-curricular and project-oriented activities, including students interacting with food within an art-based, creative universe. From 2015 to 2017, 2754 students in primary and secondary levels from five schools in four municipalities participated in the project.

The aim of this chapter is to present findings from a single case study (Yin 2006) of the LOMA-local food (LOMA) project from 2015 to 2017. The chapter focuses on the integration of student creativity and professional artwork as an element in the LOMA project. The research question was formulated as follows: "How did the combination of teachers' didactic work, student creativity, and professional artwork support motivation, improve relations, and nurture the development of shared ownership among students in the LOMA project?"

\subsection{Background}

The first LOMA school in Denmark—Nymarkskolen in Svendborg—initiated the process of combining student creativity and artwork with school food activities back in 2012. ${ }^{1}$ During this year, a group of secondary students (aged 13-14) in the art class "Art and Graphic Design" collaborated in groups and developed an

\footnotetext{
${ }^{1}$ Nymarkskolen in the Municipality of Svendborg from 2011 to 2013.
} 


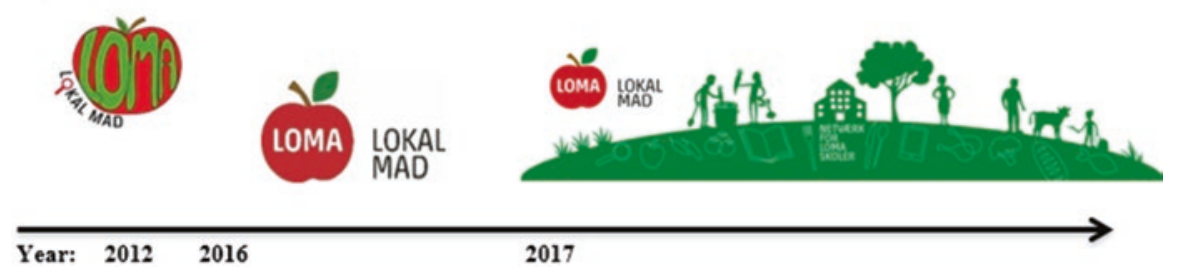

Fig. 4.1 Timeline for the development process from the initial LOMA logo made by students at secondary level to the LOMA universe

appropriate LOMA logo. The art teacher supervised the process and applied a democratic approach that encouraged student creativity. By the end of the course, student groups compared their suggestions and collectively decided on one logo that encompassed both a positive health message and a learning message (Ruge 2015; Ruge et al. 2016). The LOMA project received additional funding in 2014 because of positive results from this first LOMA school (Ruge 2015). The objective was a scaling-up of the LOMA approach to five more schools. ${ }^{2}$ Originally, the pencildrawn illustration developed by the students at Nymarkskolen was intended to be the logo to be used across all of the six schools in the project. However, it turned out to be too difficult to reproduce the hand-drawn analog logo for letterhead, digital homepage, print, social media, online educational materials, certificates, and other shared items. Consequently, the project management team and the steering group (consisting of headmasters from all schools) contacted a professional artist ${ }^{3}$ to develop a graphic design for a logo, based on the original. It was the intention to use it in the "LOMA universe" to inspire students' creative imaginations and involvement in the activities. (See the logo development process in Fig. 4.1.)

The LOMA universe was a visual environment for the school setting that supported and communicated the LOMA school "ethos" and invited students to engage in educational activities, not only in a physical way (e.g., cooking) but also in a creative and imaginative way with ideas and visions. During 2015-2016, the artist developed the LOMA universe in collaboration with the project management team, the steering group, and teachers.

In the first stage, the new logo was created and modified for multiple format use. The "looking glass" and other smaller details from the initial hand-drawn logo were difficult to transfer to the new logo, and it was with regret that the steering group decided to eliminate them. While disappointed, they acknowledged that the colors in the new logo were brighter, the writing of the name was more distinct, and the new logo was more versatile for sharing across media platforms. In the second stage, the initial vision from the participants was to form a tree with multiple LOMA apples, one for each school. However, this endeavor suffered similar problems with the reproduction of smaller details in the different formats and required creative

\footnotetext{
${ }^{2}$ Supported by Nordea-fonden. See more at www.lomaskole.dk

${ }^{3}$ The name of the Danish professional artist is M. Madsen.
} 
modification. Through an interactive process between the artist and participants, the idea of depicting the LOMA universe as a curved surface of the Earth with onedimensional figures was put forward. Through a participatory dialogue, the result was a simplistic depiction of an integrated ecosystem with inhabitants and natural and cultural artifacts. The central elements were the Earth, the tree, the sun, the sky, the school, and the collaborating students. In the green ground, there were multiple analog and digital "tools for learning," such as a book, bread, an apple, a fish, a plate, a fork and knife, an iPad, and a looking glass. Later, the artist added other human elements (e.g., a teacher and a farmer) and some animals with supportive functions in the universe. In the third stage, the focus was on not "overloading" the universe and instead leaving open space for student interpretation, imagination, and creativity. In the beginning of 2016, LOMA teacher-training courses introduced teachers to the graphic design of the LOMA universe. Teachers were trained in pedagogical and didactical methods to support student creativity and to encourage students to use their imagination to invent "food stories" inspired by the LOMA universe illustration. Responding positively to these ideas, teachers requested larger posters depicting the LOMA universe to use as a shared frame for class activities in school.

\subsection{Conceptual Framework}

The conceptual framework for the health promotion efforts of the program was based on the Ottawa Charter and its description of the fundamental resources for health: "peace, shelter, education, food, income, a stable ecosystem, sustainable resources, social justice and equity. Improvement in health requires a secure foundation in these basic prerequisites" (WHO 1986, p. 1). Since 1986, this statement has been widely accepted and integrated in global public health definitions and strategies (White et al. 2013). The Ottawa Charter also forms the foundation for various health promotion settings, including promoting healthy food consumption in early-life settings such as schools and kindergartens, since eating patterns formed in childhood tend to track into adulthood (Langford et al. 2014; SHE Network 2018; WHO 2018). Furthermore, the WHO suggests the application of an educational approach to health promotion. This case applies social constructivist theory to the relationship between health promotion, art-based student creativity, food, and learning as social practice in schools (Jensen and Simovska 2005; Ruge 2015; Vygotsky 2004; WHO 1986). Following this, cultural norms structure social practices such as food growing, food preparation, food procurement, and food consumption. Furthermore, cultural norms at home, in school, and in social media shape the way students in school relate to food. As a social practice, food in schools can be integrated with other social practices and guided by teachers' didactic work in curriculum activities such as cooking, health education, and science.

In this study, there was a special focus on how artwork in curriculum and food activities was integrated into the LOMA project. By including art, teachers' didactic 
work encouraged student creativity. This approach is supported by the theory of Vygotsky that emphasizes the importance of nurturing creativity in children. (Vygotsky 2004). According to Vygotsky (2004), not only art teachers but also professional artists can contribute to the cultivation of student creativity in schools. In support of including professional artists in educational activities, Dewey (2005) has stated that the experience of art will accentuate the quality of belonging to a large whole: the universe in which we live (Dewey p. 214).

For comparison, the Nottingham Apprenticeship Model is an example of how a systematic and structured partnership on "learning for the arts" between professional artists and schools can contribute to student creativity and "revitalize education in the arts" and other creative activities as well (Griffiths and Woolf 2009, p. 17-18). In the Nottingham project, artists led the activities, whereas teachers led the activities in the LOMA project. The advantage of teacher-led activities is that the teacher is not a "passive spectator," but rather is embedded in the school so the activities can continue after the artist has left the school. This difference is fundamental for the distribution of roles and responsibilities between teachers and artists-and for student outcomes. If teachers select a didactical model that encourages creative imagination in artwork, teacher-led activities will support the development of student creativity, critical thinking, and positive relations between students and teachers.

This approach is also supported by the works of Freire (2018), who emphasized how a dialogical approach to education encourages people to use their creative power as they develop the ability to critically reflect on challenges in life (Freire 2018). For schools, Freire described the importance of dialogical, problem-posing, and collaborative pedagogical methods as opposed to mainstream 'banking' educational methods with the aim of promoting critical awareness among students.

In a twenty-first century educational context, the work of Fullan and Langworthy on new pedagogies also emphasizes the importance of dialogical, visionary, and collaborative approaches in school:

\begin{abstract}
We need our learning systems to encourage youth to develop their own visions about what it means to connect and flourish in their constantly emerging world and equip them with the skills to pursue those visions. This expansive notion, encompassing the broader idea of human flourishing, is what we mean by "deep learning." (Fullan and Langworthy 2013)
\end{abstract}

In conclusion, creative collaboration between teachers and students is linked to critical thinking about the possibility of change. In the case of LOMA-project the creative collaboration is linked to the request for more sustainable and climatefriendly food systems via local food sourcing and cooking. Based on this understanding, this chapter will describe and analyze a specific case from the LOMA project. The categories for analysis are divided in the physical, organizational, didactical, and socio-cultural dimensions, to analyze school foodscapes (Dolphijn 2004; Ruge 2015). ${ }^{4}$

\footnotetext{
${ }^{4}$ For clarification: In the following analysis, the term "LOMA universe" represents the graphic design (cf. Fig. 4.1). The term "LOMA foodscape" represents the total educational setting at the school as a whole.
} 


\subsection{Planning and Conducting LOMA Teaching}

The LOMA approach seeks to integrate food activities into the general curriculum and into educational activities. Importantly, this approach centers LOMA teaching as important for all activities in the LOMA project. Often primary- and secondarylevel schools planned a number of 'LOMA weeks' for the whole school year. In a LOMA week, schools applied a project-oriented approach in which teachers could collaborate on LOMA themes across subjects throughout all five school days. The LOMA project consultants initiated planning of the LOMA weeks during schoolbased training for teachers. In addition to teachers, teacher assistants and kitchen managers also participated as "educators" in the training activities. The teacher-training course encompassed theory and methods in LOMA pedagogy and didactics (see Table 4.1). The training included an action-learning element, in which

Table 4.1 The modules in the "LOMA education model" for teachers

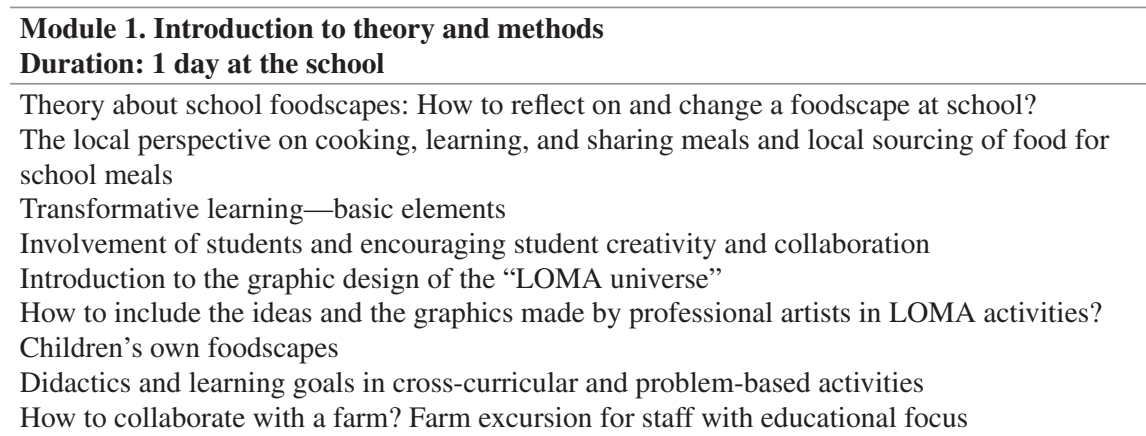

\section{Module 2. Teacher-teams plan their own LOMA week \\ Duration: 1 day at the school}

Teacher teams, select subjects and learning goals and integrate student creativity in educational activities. Decisions made on art forms and student outputs Meeting with students to invite them to participate in planning of LOMA week

Contact collaborators and organize logistics and plans for teamwork (online)

Establish heterogeneous groups across classes (teacher task)

Plan workshops, farm visits, and menus. Send information to parents 2 weeks in advance

\section{Module 3. Teacher-teams conduct a LOMA week with students \\ Duration: 5 days at the school for teachers and students}

Excursion for students to a local farm. Reflections before, during, and after in relation to learning goals for 'LOMA-week'

Conduct workshops with students. Rotations during the week: all groups work 1 day in each of the workshops from 8 AM to 2 PM

Each day, the student groups and their teachers share a joint meal at lunch prepared by students, teachers, and the kitchen manager: todays cooking-team

Dissemination of student artwork and other creative products from student groups; sharing artwork among student groups. Often using ICT or exhibitions in the hall

Inviting "friendship classes," school management staff, or parents for a meal. Visit from LOMA project management team, evaluations, team reflections, and "lessons learned"

Evaluation with students, colleagues, and consultants. Sharing knowledge with the following teacher-team for the next 'LOMA-week' at the school 
teachers were encouraged to work dialogically? as a social learning group, or a "community of practice" (Fullan and Langworthy 2013; Ruge et al. 2016; Wenger et al. 2002). The implication of this was that all participants were "learners" and all contributions were welcomed without regard to professional status. Teacher-teams often used a five-day workshop model for a LOMA week. All teachers were able to attend during their regular teaching schedule, and this facilitated a thematic, projectoriented, didactical model for students' work. Over 5 days, all students worked in shifts in all five workshops. The workshop on "cooking a joint meal for peers" was compulsory for teachers to include in the plan.

\subsection{Case Study of a LOMA Week in a Primary School}

The categories for analysis of this case focus on the organizational, didactical, socio-cultural, and physical dimensions, drawing on the conceptual framework previously described for analyzing "LOMA school foodscapes" (Dolphijn 2004; Ruge 2015). The objects, events, and activities in these different dimensions comprised the following:

(a) Organizational dimension: During teacher training modules, eight teachers, one kitchen manager, and one teacher assistant planned their LOMA week. They divided six classes of first-graders (aged 6-7 years) into four working groups across classes (110 students total) in order to improve interaction, collaboration and positive relations among students. All working groups spent 1 day in each workshop during the week.

(b) Didactic and socio-cultural dimensions: Teachers represented in total more than 20 different school subjects, because each teacher could teach three different subjects. The team had to decide on a joint cross-curricular theme for the project before they chose the subjects and learning goals. In this case, they agreed on "Apple" as a theme that functioned as an overall frame that was open for student creativity and suggestions from teachers and the kitchen staff. Five workshops were established, with each workshop covering two subjects. In the "Language \& Media" workshop (see Figs. 4.2 and 4.3, teachers encouraged students to use "child spelling," where the students imagined the best way to spell the word. Students seemed confident with this and were not embarrassed about eventual errors. As a way of supporting student recognition and ownership, teachers used the LOMA logo on the board and on student materials. All students and all teachers shared and enjoyed the food that students cooked each day during the LOMA week. The kitchen manager adjusted the food production to primary level of competences.

(c) Physical dimension: In the "Art \& Science" workshop, students learned about the LOMA universe and the importance of trees, especially apple trees. Pupils 
followed the botanical development from seed to tree. They cut apples, picked the seeds, and learned how to plant them. They imagined how trees would grow on Earth and made drawings of this. Students worked in smaller groups to produce food-art pictures from fresh carrots, apples, and other vegetables. They took digital photos of their food-art and presented them to peers by the end of the workshop and on posters in the hall (see Figs. 4.2 and 4.3). Students archived photos on iPads to share with parents. In the "Language \& Media" workshop, students created books with narratives based on their own experiences and learning. They used their photos from other workshops or they visited the other groups and took photos of peers "in action" (see Fig. 4.4).

Based on data from each dimension, there are indications of how the combination of teachers' didactic work with professional artwork (the logo and framing of the "LOMA universe") and student creativity (students' own artwork) supported recognition and motivation among students, such as when they created their "vegetable-art" pictures. Furthermore, students developed knowledge (e.g., about trees) and skills (e.g., cutting apples). Students also seemed to develop self-esteem and an ownership in the form of being proud to show their joint artwork to other peers and to the whole school. The following transcript of data is based on a semi-structured focus group interview (Kvale 2008) with students, who had engaged in digital creative learning activities by using their Ipad (cf. Fig. 4.4).

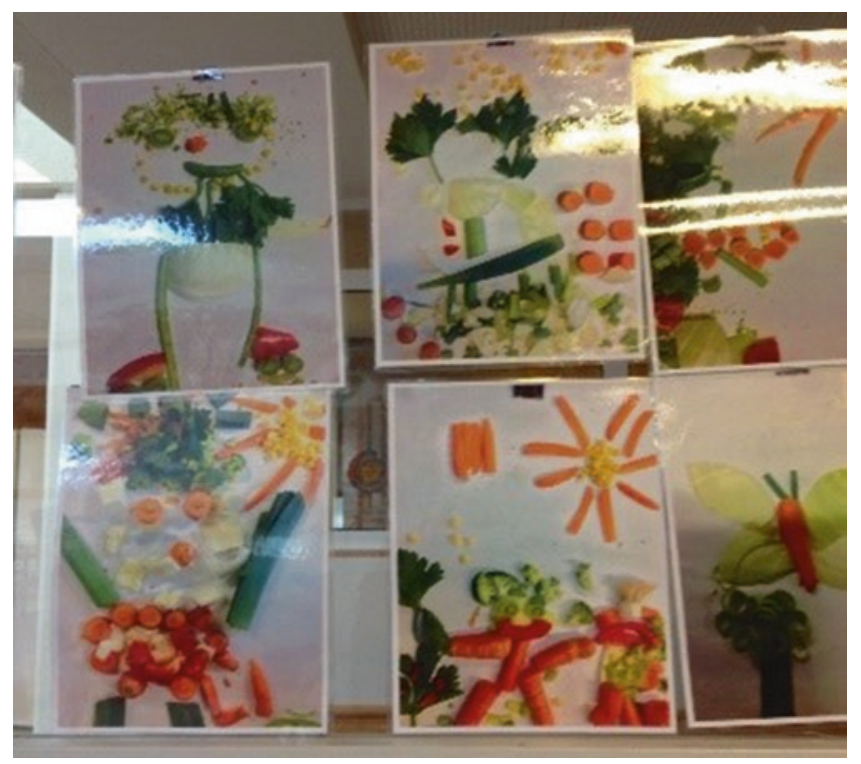

Figs. 4.2 and 4.3 Pictures of "vegetable-art" created by primary level students (aged 6-7 years) and shared on posters in the hall and online via iPads and smartboards 


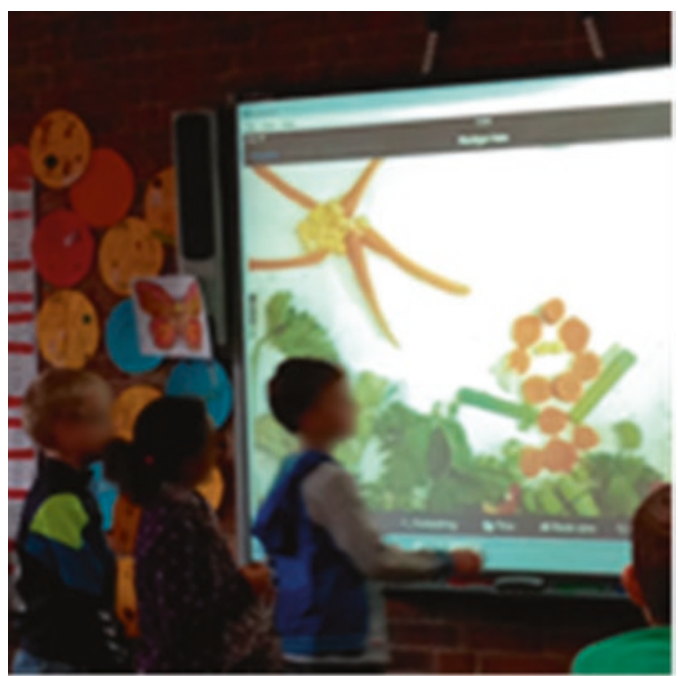

Figs. 4.2 and 4.3 (continued)

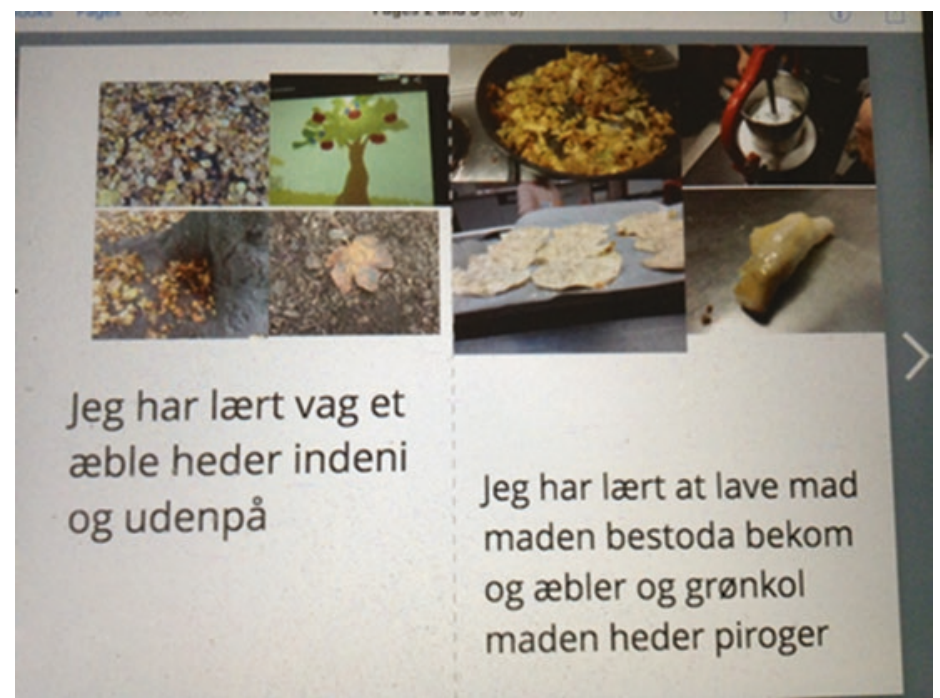

Fig. 4.4 Student creativity via digital "journal books" made on iPads with students' own photos from the LOMA project. Translation of text in 'child-spelling': "I have learned wat an apple is caled inside and outside. I have learned to cook... the food was made of apples and green-cabage and was caled piroger" (in child-spelling) 


\section{$\mathrm{I}=$ interviewer;}

\section{R3, R4, R5 = student respondents (aged 6 years)}

I: What did you do today?

R4: Hmm...It's a "book creator," it's called...

I: What is it all about, can you tell me?

R4: $\quad$ Yes, you can make a lot of books with it.

I: How is that?

R4: You can take pictures and video, and then you can insert it, because there is lots of pages and such. We have made our journal book /on it/.

I: What is it used for, that journal book?

R3: I think you can make as many pages as you like. You can also make recordings of sounds and much more [doing gestures with hands to illustrate].

I: What should it be used for?

R5: It will be used to show all the other primary classes and the pre-primary classes, and I believe the other classes, too.

I: What are you going to show them?

R5: $\quad$ Show them the book.

I: What is it about?

R5: It's about what we have made. We have made food in "Nature and Technology" and in "Danish" and "Mathematics."

I: So these are the subjects that have been involved this week?

R4: - yes, and "Food."

The voices of these three respondents represent the larger group of students as "one student voice." Considering this, there are indications that students did improve their relations with one another during participation in the variated "LOMA foodscape"-both in the smaller group ("what we have made") and also by a shared ownership with the larger group ("show all the other primary classes"). Students seemed conscious about their own creative contribution and how this was a connection to the "larger whole" - to the school community. They also seem to have gained self-esteem and pride in showing their creative work to other students. Finally, students seemed to have developed basic knowledge about food, as well as insight into how food was integrated with other subjects in school. Based on data from the various dimensions, there are indications of students feeling a shared responsibility and ownership toward the whole "LOMA school foodscape" that seems to make sense to them.

\subsection{Evaluation of Case Study}

The research question for this study focused on how the combination of teachers' didactic work, student creativity, and professional artwork supported motivation, improved relationships, and nurtured the development of a shared ownership among participants in the LOMA project.

Based on results from analysis of the representative single-case at the primary level in one of the LOMA schools, there are indications that the combination of 
teachers' didactic work with professional art and student creativity, supported improved relations, well-being and the development of a shared ownership among students. It seems as if creativity had been cultivated with good results during the project. Additionally, students seemed to have developed components of action competence with regard to food and health in the form of new knowledge and skills, self-esteem, experience with real-life challenges, and experience with collaboration (Jensen and Simovska 2005; Ruge 2015).

The program theory of the LOMA project was evaluated by The Danish Evaluation Institute from 2015 to 2017. They concluded that student and teacher participation led to improved relations, and development of shared ownership in the health-promoting "learning environment" and to an experience of "enthusiasm" (Danish Evaluation Institute 2017). The overall framing of the project by the shared logo and the visual "LOMA universe" seems to have supported these findings. In Denmark, the notion of "enthusiasm" among all students is not often connected to school activities. Children in primary school often report feel "bored" in traditional Danish and Math classroom lessons, and so the cultivating of enthusiasm and creativity through shared ownership in a collaborative, variated learning environment is meaningful (Nielsen et al. 2017, p. 16).

Based on the findings in this case study, there are indications that teachers are adept at including student creativity in their didactic work on health promotion. However, they may need support and inspiration from professional artists to achieve learning goals and to improve well-being. There are also indications from this study that when teacher-teams collaborate in stronger professional learning groups, they can design and create learning environments that encourage student creativity and forms of "deep learning" (Fullan and Langworthy 2013). These results are supported by the general evaluation by the Danish Evaluation Institute. In addition to the recognition of improved relations among students, the Danish Evaluation Institute emphasized that the collaborative and creative approach in the LOMAproject also seemed to have improved relations among staff as well.

\subsubsection{Limitations and Implications}

There are limitations to this study that could have benefitted from analysis of multiple cases. Certainly, there was a variety of results from the participating schools, and some schools responded to the idea of the "LOMA universe" in a more positive way than others. Art teachers especially showed positive agency and interest, which could have been further examined. Sometimes the informal hierarchies among teachers had a strong influence on the planning of workshops, which meant that ideas to enhance student creativity did not gain support from colleagues. This is an argument for initially establishing a special "bond" between the external artists and the art teachers during teacher-training modules.

Implications for future research suggest that action-research approaches are needed to develop research designs based on social constructivist theory and critical social theory. Holistic, action-learning designs that can capture development and 
changes both in the "whole school system" and for the "whole human being," among students and teachers alike. Unfortunately, the current challenges to planetary health and sustainable development are closely linked to human health. Therefore, creative imagination and critical thinking are in demand for the future worldwide. A holistic and integrated approach to food in schools might be a good way to promote health, well-being, and sustainable development in practice.

\subsection{Conclusion}

Healthy food in schools should not only be about food, nutrition, taste, programs and systems. Food in schools should include teachers' planning of dialogical learning processes from a problem-based and project-oriented didactic approach, that provide space for creative imagination and critical thinking. Currently, the notions of "healthy eating", "food literacy" and "food technology" tend to have a reductionist and hegemonic influence on school food discourse (Traverso-Yepez and Hunter 2016). As in other settings and in related general understandings of health (see Chap. 21, in this volume), these notions and approaches to school food provision seem to be predominantly based on individualized, market-oriented, and "Western" conceptions. The findings support the notion that it is important to scaffold teachers in how to didactically include student creativity in health promotion activities and other similar initiatives. Doing so is a way to support and stimulate participation not only of "the student as taster," "the student as eater," and/or "the student as consumer or producer," but especially of the "whole creative and learning human being." There are indications that the "whole school' and 'whole system approach' might benefit from applying a "fully human" Freirean perspective in an updated version, aimed at "deep learning." This could be advantageous not in order to individualize the challenges in health, but rather to give teachers the opportunity to invite children and adolescents into dialogical learning processes as "whole" human beings with creativity, multiple competences, emotions, bodily and emotional needs, skills, backgrounds, and identities.

Acknowledgments I would like to thank the students, teachers, kitchen managers, and headmasters who made this study meaningful and possible. I am also grateful to artist Marie Madsen for her collaboration and creative contribution to the LOMA-local food project.

\section{References}

Brembeck, H. (2009). Childrens' becoming in frontiering foodscapes. In A. James, A. Kjørholt, \& V. Tingstad (Eds.), Children, food and identity in everyday life. New York: Springer.

Danish Evaluation Institute. (2017). Evaluation of the LOMA project. Evaluation report. https:// www.eva.dk/grundskole/evaluering-projektet-loma. Accessed Nov 2018. 
Danish Ministry of Education. (2019). Agreement on school reform 2013. Available online. https:// eng.uvm.dk/primary-and-lower-secondary-education/the-folkeskole/about-the-folkeskole. Accessed Nov 2019.

Dewey, J. (2005). Art as experience. In S. D. Ross (Ed.), Art and its significance: An anthology of aesthetic theory. Albany: State University of New York Press.

Dolphijn, R. (2004). Foodscapes: Towards a Deleuzian ethics of consumption. The Netherlands: Eburon Publishers.

Freire, P. (2018). Pedagogy of the oppressed. USA: Bloomsbury Publishing.

Fullan, M., \& Langworthy, M. (2013). Towards a new end: New pedagogies for deep learning. Seattle: Collaborative Impact.

Griffiths, M., \& Woolf, F. (2009). The Nottingham apprenticeship model: Schools in partnership with artists and creative practitioners. British Educational Research Journal, 35(4), 557-574.

Jensen, B. B., \& Simovska, V. (2005). Involving students in learning and health promotion processes - clarifying why? what? and how? Health Promotion \& Education, 12(3-4), 150-156.

Kvale, S. (2008). Doing interviews. Thousand Oaks: Sage.

Langford, R., Bonell, C. P., Jones, H. E., Pouliou, T., Murphy, S. M., Waters, E., et al. (2014). The WHO Health Promoting School framework for improving the health and well-being of students and their academic achievement. Cochrane Database of Systematic Reviews, (4), CD008958.

Nielsen, C. P., Keilow, M., \& Westergaard, C. L. (2017). Elevernes oplevelser af skolen i folkeskolereformens tredje år. VIVE Report (in English: Student experience of school in the third year of 2014 reform). Available online. https://www.vive.dk/da/udgivelser/elevernes-oplevelser-af-skolen-i-folkeskolereformens-tredje-aar-en-kortlaegning-6832/. Accessed Nov 2018.

Rasmussen, M., Kierkegaard, L., Rosenwein, S. V., Holstein, B. E., Damsgaard, M. T., \& Due, P. (2019). Skolebørnsunders øgelsen 2018: Helbred, trivsel og sundhedsadfærd blandt 11-, 13-og 15-årige skoleelever i Danmark (in English: Health behaviour in school-aged children: students aged 11, 13 and 15 years in Denmark). http://www.hbsc.org/

Retsinformation. (2018). Legislation of public schools. Folkeskoleloven. https://www.retsinformation.dk/Forms/r0710.aspx?id=196651. Accessed Nov 2018.

Ruge, D. (2015). Integrating health promotion, learning and sustainable development (Dissertation). University College Lillebelt and Aalborg University.

Ruge, D., Nielsen, M. K., Mikkelsen, B. E., \& Bruun-Jensen, B. (2016). Examining participation in relation to students' development of health-related action competence in a school food setting: LOMA case study. Health Education, 116(1), 69-85.

Ruge, D., Puck, M., \& Hansen, T. I. (2017). Report 1. Foreløbige resultater fra analyse af LOMA intervention (in English: Preliminary results from analysis of LOMA intervention). Quantitative methods. University College Lillebelt, Department of Pedagogy and Society, Odense.

Sabinsky, M. S. (2013). Healthy eating at schools. How does a school food program affect the quality of dietary intake at lunch among children aged 7-13 years? DTU, Denmark.

SHE Network. (2018). Schools for health in Europe. http://www.schools-for-health.eu/she-network. Accessed May 2019.

Simovska, V. (2012). What do health-promoting schools promote? Processes and outcomes in school health promotion. Health Education, 112(2), 84-88.

Simovska, V., Nordin, L. L., \& Madsen, K. D. (2015). Health promotion in Danish schools: Local priorities, policies and practices. Health Promotion International, 31(2), 480-489.

Stovgaard, M., \& Wistoft, K. (2018). Rammer for mad og måltider i skolen—en forskningsrapport (in English: Framing food and meals in school-report from intervention study). Aarhus University-DCA-Nationalt Center for Fødevarer og Jordbrug.

Stovgaard, M., Thorborg, M. M., Bjerge, H. H., Andersen, B. V., \& Wistoft, K. (2017). Rammer for mad og måltider i skolen: en systematisk forskningskortlægning (in English: Framing food and meals in school: a systematic review). Aarhus University-DCA-Nationalt Center for Fødevarer og Jordbrug.

Traverso-Yepez, M., \& Hunter, K. (2016). From "healthy eating" to a holistic approach to current food environments. SAGE Open, 6(3), 2158244016665891. 
Vygotsky, L. S. (2004). Imagination and creativity in childhood. Journal of Russian \& East European Psychology, 42(1), 7-9.

Wenger, E., McDermott, R. A., \& Snyder, W. (2002). Cultivating communities of practice: A guide to managing knowledge. Boston: Harvard Business Press.

White, F., Stallones, L., \& Last, J. M. (2013). Global public health: Ecological foundations. New York/Oxford: Oxford University Press.

World Health Organization. (1986). The Ottawa charter for health promotion. http://www.who.int/ healthpromotion/conferences/previous/ottawa/en/. Accessed May 2019.

World Health Organization. (2018). Global school health initiative (Health Promoting Schools partnership). http://www.who.int/school_youth_health/gshi/en/. Accessed May 2019.

Yin, R. (2006). Case study research: Design and methods. Applied social research methods series (Vol. 5, pp. 25). London: Sage Publications.

Open Access This chapter is licensed under the terms of the Creative Commons AttributionNonCommercial-NoDerivatives 4.0 International License (http://creativecommons.org/licenses/ by-nc-nd/4.0/), which permits any noncommercial use, sharing, distribution and reproduction in any medium or format, as long as you give appropriate credit to the original author(s) and the source, provide a link to the Creative Commons license and indicate if you modified the licensed material. You do not have permission under this license to share adapted material derived from this chapter or parts of it.

The images or other third party material in this chapter are included in the chapter's Creative Commons license, unless indicated otherwise in a credit line to the material. If material is not included in the chapter's Creative Commons license and your intended use is not permitted by statutory regulation or exceeds the permitted use, you will need to obtain permission directly from the copyright holder.

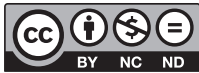

